\title{
Evaluation of rat insulin messenger RNA in pancreatic and extrapancreatic tissues
}

\author{
S.J.Giddings ${ }^{1}$, J.Chirgwin ${ }^{3}$ and M.A. Permutt ${ }^{2}$ \\ ${ }^{1}$ Washington University Medical Service United States Veterans Administration Medical Center, John Cochran Division and \\ ${ }^{3}$ Departments of Medicine and ${ }^{2}$ Anatomy and Neurobiology, Washington University School of Medicine, St. Louis, Missouri, USA
}

\begin{abstract}
Summary. The purpose of these studies was to determine whether insulin detected immunochemically in extrapancreatic tissues of the adult rat is synthesized in situ by quantitating mRNA in these tissues. A blot hybridization assay was utilized with cloned ${ }^{32} \mathrm{P}$-proinsulin $\mathrm{cDNA}$. The lower limit of detection was estimated to be 3pg. Proinsulin mRNA concentration was found to be $1000-1500 \mu \mathrm{g}$ in isolated pancreatic islets and was easily detected in total pancreatic RNA at $10-15 \mathrm{pg} /$ $\mu \mathrm{g}$. Proinsulin mRNA was quantitated in rat insulinoma cells adapted to culture at levels 1:50 those in normal islets. Samples of RNA (20-50 $\mu \mathrm{g})$ enriched about 50 -fold for mRNA sequences by repeated oligo-deoxythymidylate chromatography were assayed. No insulin mRNA was detected in $50 \mu \mathrm{g}$ samples of RNA from brain or in $20 \mu \mathrm{g}$ samples from subsec-
\end{abstract}

tions of brain or other extrapancreatic tissues. RNA samples were undegraded as assessed by ability to stimulate protein synthesis in a cell-free system. Proinsulin mRNA from pancreas was added to brain homogenates and recovered intact. Brain RNA samples with insulin mRNA levels 1:1000 that of pancreas would be predicted to have $50-75 \mathrm{pg}$ proinsulin mRNA/ $50 \mu \mathrm{g}$ sample assayed if present. Because none was found, brain must have a concentration $<1: 6,000$ that of pancreas. These findings suggest that immunoassayable insulin detected in extrapancreatic tissues of the adult rat is synthesized by the pancreas.

Key words: RNA blot hybridization, rat, proinsulin mRNA, brain mRNA, pancreatic islets.
A number of peptides originally described as hormones from gut have been identified in brain [1,2]. Some are present in approximately equal concentrations in hypothalamus and gut (e.g. somatostatin) [3]. Others, such as insulin, are present at levels 1000 -fold less in brain than in pancreas $[4,5]$. The identification of pg quantities of less abundant peptides per $\mathrm{g}$ of brain has been facilitated by radioimmunoassays and by localization with immunocytochemical techniques [1-5].

The immunochemical detection of hormones in brain leaves unanswered the important question of their origin. Demonstration of insulin synthesis in brain or elsewhere would strongly imply as yet undescribed functions for this peptide. There are no data to answer this question, except reports of increased levels of insulin in brain compared with plasma under various conditions [4-6]. The low abundance of insulin in brain precludes the use of radiolabelled amino-acid incorporation to document synthesis directly [7].

Using an RNA blot hybridization technique, we have assayed for proinsulin I and II mRNA's (which are $93 \%$ homologous) in brain and several other tissues of the adult rat, using a cloned ${ }^{32} \mathrm{P}-$ labelled probe complementary to rat insulin I mRNA [8]. Proinsulin I cDNA hybridizes readily to both genes under the conditions of hybridization employed [9]. The presence of proinsulin mRNA in extrapancreatic tissues would provide an independent line of evidence for synthesis. The present limit of sensitivity of this assay is about $5 \mathrm{pg}$ of proinsulin mRNA in $50 \mu \mathrm{g}$ of RNA $(0.00001 \%)$. Because amino-acid incorporation requires that a protein represent at least $0.1 \%$ of total protein synthesis, the mRNA assay is approximately 10,000 -fold more sensitive. Using this approach, we have estimated the abundance of proinsulin mRNA in pancreas and in extrapancreatic tissue.

\section{Methods}

\section{RNA extraction}

Several organs were dissected from anaesthetised (pentobarbitol sodium, $3 \mathrm{mg} / \mathrm{kg}$ ) male Sprague-Dawley rats (weight 200-300 g), blotted, weighed and total and poly-adenylated(Poly A+)RNA prepared by the method of Chirgwin et al. [10] using sedimentation through CsCl. Poly A+RNA was prepared from total cellular RNA by two cycles of oligo deoxythymidylate (dT)-cellulose (Collaborative Research, Lexington, MA) as described previously [11]. RNA recovered was $1.6-2.0 \%$ of input RNA. Islets of Langerhans were isolated by collagenase digestion [12] as described previously [13]. RNA pooled from 6-20 rats was used for analysis, excepting pancreas where RNA from 2-6 rats was used. Three preparation of RNA were analyzed on five occasions.

Quality of isolated RNA was checked by $A_{260 \mathrm{~nm}}$ to $A_{280 \mathrm{~nm}}$ ratios $>$ 2.0; electrophoresis under denaturing conditions of total RNA, which was visualized by staining with 1 -ethyl-2-[3-(1-ethylnaphtho[1,2d] thiazolin-2-ylidiene)-2-methylpropenyl] naphtho[1,2d] thiazolium bromide (Stainsall, Eastman-Kodak, Rochester, NY) (ratio of $28 \mathrm{~S}$ to $18 \mathrm{~S}$ 

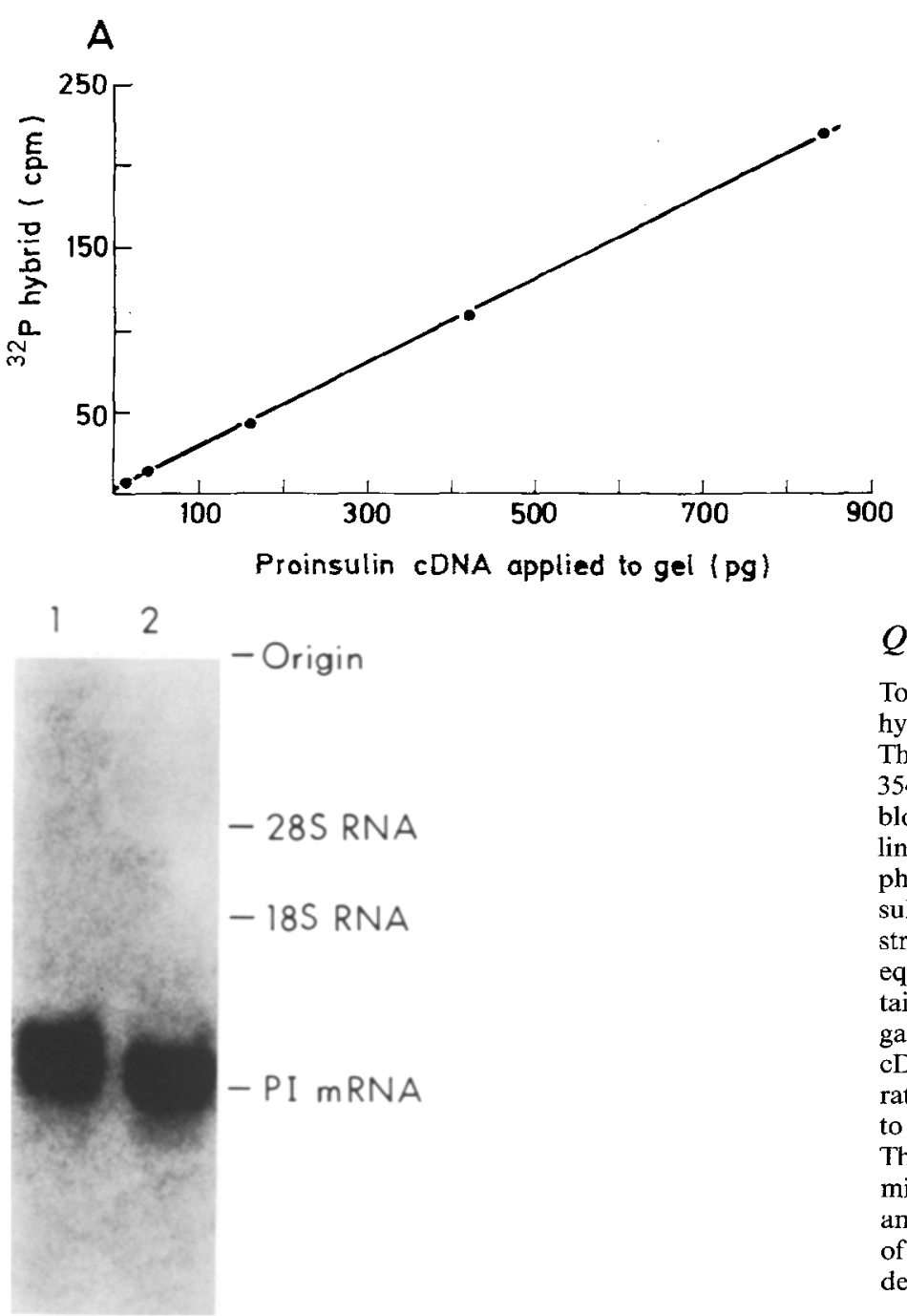

Fig. 2. Estimation of proinsulin mRNA in isolated rat pancreatic islet RNA and insulinoma cell RNA. RNA $(20 \mu \mathrm{g})$ from insulinoma cells adapted to culture (lane 1) was compared to rat pancreatic islet RNA $(1 \mu \mathrm{g}$, lane 2$)$, by blot hybridization analysis with ${ }^{32} \mathrm{P}$-proinsulin cDNA as described in the Methods. Size was deternined from $18 \mathrm{~S}$ and 28S RNA standards electrophoresed in adjacent lanes. Exposure time, $73 \mathrm{~h}$

peak heights $\sim 2$ ), and cell-free translation. Brain poly $A+R N A$ was translated using a kit from rabbit reticulocyte lysate according to the direction of the manufacturer (Promega-Biotec, Madison, WI). Products were assayed by SDS-polyacrylamide (Eastman-Kodak) gel electrophoresis as described elsewhere [13].

\section{RNA hybridization analysis}

Poly A+RNA (20-50 $\mu \mathrm{g}$ ) was denatured with $1 \mathrm{~mol} / 1$ glyoxal (Fisher Scientific, St. Louis, MO) in 50\% dimethyl-sulfoxide (Sigma, St. Louis, Missouri, USA) [14] and electrophoresed on 2\% agarose gels, pre-treated with $0.2 \%$ diethylpyrocarbonate (Sigma) to inactivate nucleases potentially present in agarose. Gels were run at $23^{\circ} \mathrm{C}$ at 50 volts for $4 \mathrm{~h}$. Proinsulin mRNA size was estimated from $18 \mathrm{~S}$ and $28 \mathrm{~S}$ ribosomal RNA. RNA was transferred from gels to diazophenylthio paper (Giddings, St. Louis, MO) [15] for at least $18 \mathrm{~h}$ using $100 \mathrm{mmol} / \mathrm{I}$ sodium acetate $(\mathrm{pH}$ ) as the transfer buffer [16]. Filtres were hybridized with pre-proinsulin I clDNA cleaved from the plasmid pcRI 354 [8] and labelled to $5 \times 10^{8} \mathrm{cpm} / \mu \mathrm{g}$ with ${ }^{32} \mathrm{PO}_{4}$ by (New England $\mathrm{Nu}-$ clear Corporation, Boston, MA) nick translation [17]. Hybridization was performed at $42{ }^{\circ} \mathrm{C}$ for $24-72 \mathrm{~h}$, followed by washing and autoradiography as described previously [13].
B

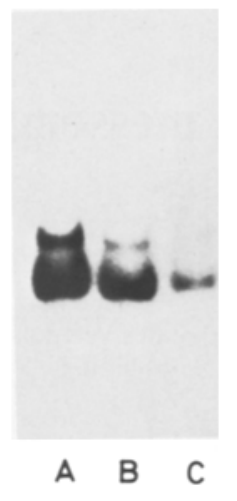

Fig. 1A and B. Quantitation of proinsulin mRNA by blot hybridization assay using a cloned complementary DNA standard. Unlabelled plasmid pcRI 354 containing rat pre-proinsulin I cDNA [8] was digested with the restriction endonuclease Hind III, denatured with glyoxal, diluted, electrophoresed, transferred, hybridized with ${ }^{32} \mathrm{P}$-proinsulin I cDNA and autoradiographed. $A$ The ${ }^{32} \mathrm{P}-$ hybrid $\mathrm{cpm}$ in relation to $\mathrm{pg}$ proinsulin cDNA applied to the gel. B Autoradiographs of ${ }^{32} \mathbf{P}$-proinsulin cDNA hybridized to $420 \mathrm{pg}$ of proinsulin cDNA (lane 1 ), $160 \mathrm{pg}$ (lane 2), and $42 \mathrm{pg}$ (lane 3). Minor bands in lanes 1 and 2 represent partially digested plasmids ( $<5 \%$ of total). Exposure time, $60 \mathrm{~h}$

\section{Quantitation of insulin $m R N A$}

To estimate proinsulin mRNA concentration in tissues by RNA blot hybridization, two different proinsulin mRNA standards were used. The first was rat pre-proinsulin I cDNA in the cloned plasmid pcRI 354 [8]. When $20-240 \mathrm{pg}$ of proinsulin cDNA were subjected to blot hybridization analysis as in Figure 1, the amount of ${ }^{32} \mathrm{P}$-proinsulin cDNA bound was proportional to the proinsulin CDNA electrophoresed. Poly A + RNA from a subcutaneously transplanted rat insulinoma [18] was utilized as the second standard since doublestranded DNA might not hybridize to the probe with an efficiency equal to that of mRNA. The insulinoma RNA was estimated to contain $0.3 \%$ proinsulin mRNA [19] and in the RNA blot hybridization gave results comparable to those obtained with cloned proinsulin cDNA (see Results). In each RNA blot analysis a known amount of rat proinsulin cDNA was electrophoresed to provide a standard and to control for variations in efficiency of transfer and hybridization. The amount of cDNA bound to specific bands on filters was determined by liquid scintillation counting (Fig.1) or by densitometric analysis (Table 1) of autoradiograms using the gel scanning accessory of a recording spectrophotometer (Beckman DU-8, Palo Alto, CA) as described previously $[9,26,32]$.

\section{Results}

\section{Proinsulin $m R N A$ in pancreatic tissue}

Isolated pancreatic islets. To determine the concentration of proinsulin mRNA in pancreatic $\beta$-cells, islets were isolated from pancreas by collagenase digestion. RNA blot hybridization with ${ }^{32} \mathrm{P}$-rat proinsulin cDNA indicated that proinsulin mRNA was $600 \pm 20$ nucleotides in length (Fig. 2 lane 2). This is consistent with about 160 poly $\mathrm{A}+$ residues attached to an mRNA of 330 coding and 110 non-coding nucleotides [8]. The concentration of proinsulin mRNA, determined using as standards either cloned rat proinsulin I cDNA (Fig.1) or poly A + RNA from a rat insulinoma, was estimated to be $1000-1500 \mathrm{pg} / \mu \mathrm{g}$ islet RNA.

Insulinoma cells adapted to culture. To demonstrate that the method may estimate proinsulin mRNA levels in tissues which synthesize less insulin, hybridization analysis was performed on RNA from rat insulinoma cells (Rin 5F) adapted to tissue culture [20]. RNA blot analysis (Fig. 2, lane 2) of $1 \mu \mathrm{g}$ of islet RNA and $20 \mu \mathrm{g}$ of insulinoma cell RNA (lane 1) indicated there was $20-30 \mathrm{pg}$ proinsulin mRNA $/ \mu \mathrm{g}$ insulinoma RNA or approxi- 


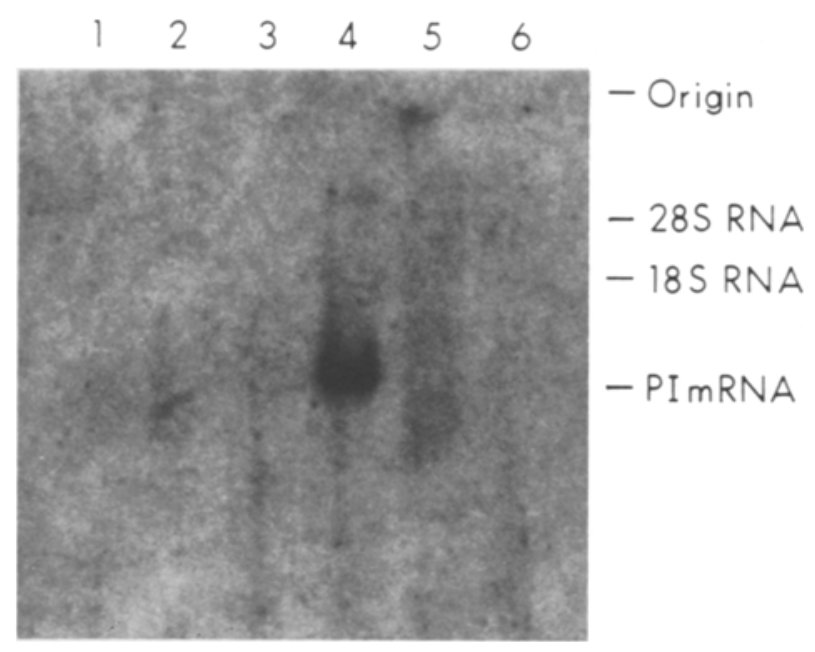

Fig.3. Estimation of proinsulin RNA concentration of pancreatic and extrapancreatic tissues. This autoradiograph compares the amount of ${ }^{32} \mathrm{P}$-proinsulin cDNA hybridizing to $20 \mu \mathrm{g}$ of total RNA from rat pancreas (lane 4 ), or $20 \mu \mathrm{g}$ of poly A+ RNA from testes (lane 1), kidney (lane 2), spleen (lane 3), liver (lane 5), and brain (lane 6). Hybridization time was increased 3-fold and the autoradiographs overexposed to facilitate detection of proinsulin $m$ RNA in extrapancreatic tissues. The apparent band at the top of lane 5 corresponds to the origin of the gel. Exposure time, 9 days

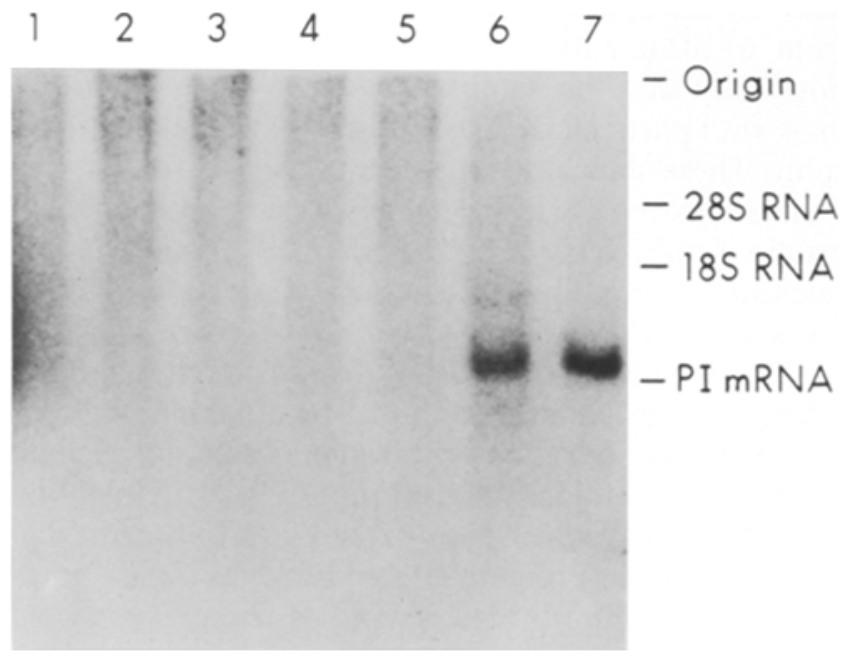

Fig.4. Proinsulin mRNA content of poly A + RNA from subsections of rat brain and guinea pig pancreas compared to that in total rat pancreatic RNA. Methods were as described in Figure 3 except that brains were dissected and poly A+ RNA $(20 \mu \mathrm{g})$ from cerebrum (lane 1), olfactory lobes (lane 2), midbrain (lane 3), cerebellum (lane 4) and hindbrain (lane 5) were subjected to RNA blot hybridization. Guinea pig pancreas poly A + RNA ( $20 \mu \mathrm{g}$, lane 6) was compared to total rat pancreatic RNA ( $20 \mu \mathrm{g}$, lane 7$)$. Stringency was descreased by lowering the temperature of the posthybridization washes from $52^{\circ}$ to $42^{\circ}$ to facilitate detection of partially homologous sequences. Exposure time, 6 days

mately $1 / 50$ that found in normal islet cells. Proinsulin mRNA from insulinoma cells appeared to be about 100 bases larger than that from normal islet cells, which is due to additional poly $\mathrm{A}+$ residues on the $3^{\prime}$ end (unpublished observations).

Total pancreatic RNA. The sensitivity of this assay allowed quantitation of proinsulin mRNA in RNA from whole pancreas without purifying poly $\mathrm{A}+\mathrm{mRNA}$
(Fig. 3, lane 4, and Fig. 4, lane 7), even through islets represent only $1 \%$ of pancreas tissue, and mRNA only $1 \%$ of total RNA. When $20 \mu \mathrm{g}$ of total RNA from pancreas was subjected to blot hybridization, it was estimated to contain $300 \mathrm{pg}$ insulin mRNA (or $15 \mathrm{pg} / \mu \mathrm{g}$ ) which was readily detected.

\section{Proinsulin $m R N A$ in extrapancreatic tissues}

RNA was isolated from several organs of rats which had been reported to contain levels of insulin greater than plasma including liver, spleen, kidney, testes, and brain [21]. To look for proinsulin mRNA in extrapancreatic tissues, polyadenylated mRNA was enriched approximately 50 -fold by oligo $\mathrm{dT}$-cellulose chromatography. The amount of proinsulin mRNA present in the poly $\mathrm{A}+\mathrm{RNA}$ fraction from these tissues (Fig. 3, lane $1-3,5$ ) was compared with that present in total pancreatic RNA (Fig.3, lane 4). While proinsulin mRNA in total pancreatic RNA was readily detected (lane 4), repeated blot hybridization failed to reveal any proinsulin mRNA in any of the other tissues. The radioautograph in Figure 3 was from an RNA filter subjected to increased hybridization time (from 24 to $72 \mathrm{~h}$ ) with ${ }^{32} \mathrm{P}$-proinsulin cDNA and deliberate overexposure which increased background. There was no detectable proinsulin mRNA in the extrapancreatic tissues examined.

To determine whether mRNA for insulin is present in brain at levels which might be detectable only in subsections, brains were quickly divided into olfactory lobes, cerebrum, midbrain, hindbrain, and cerebellum, and poly $\mathrm{A}+\mathrm{RNA}$ isolated. There was no measurable mRNA for insulin in poly A+ RNA from any subsection of brain (Fig. 4, lanes 1-5 compare with total pancreatic RNA, Fig.4, lane 7). Background hybridization in Figure 4 is prominent because the washing temperature was lowered by $10^{\circ} \mathrm{C}$ in order to determine whether RNA with somewhat divergent sequences might be present in subsections of brain (see below).

It is possible that proinsulin mRNA in extrapancreatic tissues is different from that found in pancreatic islets. To determine whether rat proinsulin I cDNA could detect $m R$ NAs for insulins which are as divergent in amino acid sequence as guinea pig [22] is from rat (about $65 \%$ homology), poly A + RNA from guinea pig pancreas was examined. At the nucleic acid level, guinea pig mRNA differs from rat I and II proinsulin mRNA by about $20 \%$ at replacement sites, and up to $40 \%$ at silent sites [23]. A single hybridizing band of mRNA was readily detected in poly A+ guinea pig pancreatic RNA (Fig. 4, lane 6), which appeared identical in size to rat proinsulin mRNA (Fig. 4, lane 7). While there is no precedent for a messenger RNA being differentially polyadenylated in various tissues, non-polyadenylated RNA from brain was examined and no insulin mRNA was found.

Because no proinsulin mRNA was detected in extrapancreatic tissue, it is important to estimate the lower limits of detection of the RNA blot hybridization method. Blot hybridization assays have been shown by oth- 
Table 1. Hybridization assay for proinsulin mRNA

\begin{tabular}{|c|c|c|c|}
\hline \multicolumn{2}{|c|}{ RNA applied to gel } & \multirow{2}{*}{\multicolumn{2}{|c|}{$\begin{array}{l}\text { Area under curve (absorbance) opti- } \\
\text { cal density }\end{array}$}} \\
\hline \multirow{2}{*}{$\begin{array}{l}\text { Total } \\
(\mu \mathrm{g})\end{array}$} & \multirow{2}{*}{$\begin{array}{l}\text { Proinsulin } \\
\text { mRNA (pg) }\end{array}$} & & \\
\hline & & Experiment 1 & Experiment 2 \\
\hline 4 & 60 & 5.06 & 3.74 \\
\hline 2 & 30 & 3.89 & 1.91 \\
\hline 1 & 15 & 0.96 & 0.29 \\
\hline 0.4 & 6 & 0.84 & 0.31 \\
\hline 0.2 & 3 & 0.46 & 0.23 \\
\hline 0.1 & 1.5 & $\mathrm{ND}^{\mathrm{a}}$ & $\mathrm{ND}^{\mathrm{a}}$ \\
\hline
\end{tabular}

${ }^{a}$ Not detected

ers to measure as little as 1-2 pg of mRNA [14, 24, 25]. The limits of the rat proinsulin mRNA assay is demonstrated by subjecting total pancreatic RNA containing $15 \mathrm{pg}$ of proinsulin $\mathrm{mRNA} / \mu \mathrm{g}$, to serial dilution and hybridization analysis. Autoradiographs were analyzed by densitometry (Table 1). The lower limits of detection of this assay was $3 \mathrm{pg}$ of proinsulin mRNA.

To demonstrate that brain RNA did not interfere with detection of proinsulin mRNA, poly A+ RNA from pancreas was diluted 10,000 -fold and added to a $20 \mu \mathrm{g}$ sample of poly A + RNA from rat brain, and analyzed. A faint but distinct band was recognized. To confirm the data in Figure 3 and 4 and to extend the sensitivity of the assay, $50 \mu \mathrm{g}$ of poly A+ RNA from brain (the maximum capacity of the gel) was electrophoresed in an adjacent lane. No hybridizing band was detected in this or other similar experiments.

Failure to detect insulin mRNA in brain might be caused by degradation during the isolation process. To test this possibility, a small amount of pancreas was added to brain and RNA isolated. A strong signal for proinsulin mRNA was present in poly A + RNA from the sample. Further evidence that brain mRNA was undegraded was provided by demonstrating that brain poly A + RNA was active in stimulating synthesis of high molecular weight brain protein in a rabbit reticulocyte cell-free protein synthesizing system (data not shown).

\section{Discussion}

Blot hybridization provides a sensitive and specific method for identification and quantitation of messenger RNA's [9, 13, 26, 30]. Cloned cDNA probes can be labelled to specific activities similar to those obtained when iodinating peptides for use in radioimmunoassays. Thus, cDNA hybridization is theoretically as sensitive an assay for nuclei acids as are radioimmunoassays for proteins.

The nucleic acid hybridization assay for protein hormone mRNA's provides a distinct advantage over immunoassay for documentation of hormone biosynthesis in situ because presence of the mRNA is a prerequisite. Using this method we have quantified insulin mRNA in islets, insulinoma cells adapted to culture and total pancreas. Because $\beta$-cell number and RNA content are known for rat islets $[13,31]$, we can estimate the $\beta$-cell insulin mRNA copy number from the data presented here to range from $50-150,000$ molecules per cell. This estimate is similar to the copy numbers of other abundant mRNA's in differentiated tissues, (e.g. casein in mouse mammary gland [27], and ovalbumin in chick oviduct [28].

These studies demonstrate that as little as $3 \mathrm{pg}$ of insulin mRNA can be detected in a RNA sample. Because no signal was detected in a $50 \mu \mathrm{g}$ sample of poly A+ RNA from brain, there is less than $0.06 \mathrm{pg}$ of insulin mRNA per $\mu \mathrm{g}$ of brain messenger RNA. Similar results were obtained for all other extrapancreatic tissues examined. This compared to $1500 \mathrm{pg}$ of insulin mRNA per $\mu \mathrm{g}$ of pancreatic mRNA. Havrankova et al. [4] and Rozensweig et al. [21] have presented data to show that levels of insulin in brain are about $20 \mathrm{ng} / \mathrm{gm}$ of tissue, as compared to $40 \mu \mathrm{g} / \mathrm{gm}$ of pancreas. Because the level of mRNA coding for a protein is roughly proportional to the amount of protein synthesized $[29,30,32]$ one would estimate insulin mRNA in brain to be 2000 -fold less abundant than in pancreas. The data here demonstrate that insulin mRNA is at maximum 6000-fold less abundant than in pancreas. In the studies by Havrankova et al. [4] and Rozensweig et al. [21] cited above, levels of insulin varied considerably from one animal to the next. In the studies presented here, RNA was pooled from 6-20 animals for each analysis, decreasing the possibility that the samples analyzed came from animals with particularly low levels ov extrapancreatic insulin. These data do not rule out the possibility that there are extremely stable, slowly turning over pools of insulin synthesized in extrapancreatic tissues at low rates and encoded by levels of messenger undetected in this study.

The insulin in other tissues demonstrated by immunoassay might be an insulin-like peptide, although bioassay and gel filtration of this material do not seem to support this view [5, 21]. In support of such an hypothesis, Rozensweig et al. [37] presented data to suggest that insulin in extracts of guinea pig brain was more "porklike" than insulin from guinea pig pancreas. The recent demonstration of only one gene for insulin in the guinea pig, encoding guinea pig pancreatic insulin [23], decreases support for distinct pork insulin-like molecules synthesized in brain. Nevertheless, we have screened for the presence of a partially homologous mRNA in brain by decreasing the stringency of hybridization. It is known that when RNA-DNA hybrids vary in sequence, they dissociate at lower temperatures than strictly homologous polynucleotides [33]. Decreasing the stringency of post-hybridization washes allowed detection of mRNA for guinea pig insulin, which is only $60-80 \%$ homologous to the rat proinsulin I mRNA [23]. These results do not exclude the possibility that a less homologous mRNA encodes the insulin reported in brain. Examples of distantly related members of the insulin gene family include IGF I and II $[34,35]$ and pre-prorelaxin [36]. These mRNA's which are partially homologous to proinsulin mRNA encode proteins with distinctly different immunoactivity and biological activity. Because insulin mRNA is not found in extrapancreatic tissues at 
levels considerably lower than those predicted by their insulin content, this suggests that the insulin found in brain and other tissues is not synthesized there, but more likely originates in pancreatic $\beta$-cells.

Acknowledgements. We would like to thank Dr. W.Chick for generously supplying us with insulin-producing rat insulinoma cells adapted to tissue culture, and Dr. P.Lomedico for supplying poly A+ RNA from rat insulinoma. Dr. P. Rotwein provided valuable advice and reviews of this manuscript. We would like to thank C. Fleischmann for excellent technical assistance and P. Rader and P. Stewart for excellent assistance in preparing the manuscript. This work was supported by National Institute of Health grant AM-16746 and the United States Veterans Administration.

\section{References}

1. Rehfeld J (1978) Immunologic studies on cholecystokinin II. Distribution and molecular heterogeneity in the central nervous system and small intestine of man and hog. J Biol Chem 253: 4022-4030

2. Nakata Y, Kasaka Y, Segawa T, Yajimi H, Kitagawa K (1978) Substance P: regional distribution and specific binding to synaptic membranes in rat central nervous system. Life Sci 22: 259-268

3. Vale W, Ling N, Rivier J, Villarreal J, Rivier C, Douglas C, Brown M (1976) Anatomic and phylogenetic distribution of somatostatin. Metabolism 25: 1491-1494

4. Havrankova J, Schmechel D, Roth J, Brownstein M (1978) Identifrcation of insulin in rat brain. Proc Natl. Acad Sci 75: 5737-5741

5. Le Roith D, Hendricks SA, Lesniak MA, Rishi S, Becker KL, Havrankova J, Rozensweig JI., Brownstein MJ, Roth J (1983) Insulin in brain and other extrapancreatic tissues of vertebrates and nonvertebrates. Adv Metab Disorders 10: 303-340

6. Eng J, Yalow RS (1980) Insulin recoverable from tissue. Diabetes 29: 105-109

7. Howell SL, Taylor KW (1967) The secretion of newly synthesized insulin in vitro. Biochem $J$ 102: 922-927

8. Cordell B, Bell G, Tsicher E, DeNoto FM, Ullrich A, Pictet R, Rutter WJ, Goodman HM (1980) Isolation and characterization of a cloned rat insulin gene. Cell 18: 533-543

9. Kakita K, Giddings SJ, Rotwein PS, Permutt MA (1983) Insulin gene expression in the developing rat pancreas. Diabetes 32: $691-696$

10. Chirgwin JM, Przybyla AE, MacDonald RJ, Rutter WJ (1979) Extraction of RNA from tissues enriched in ribonuclease. Biochemistry 24: $5294-5299$

11. Aviv H, Leder P (1972) Purification of biologically active globin messenger RNA by chromatography on oligothymidylic acid-cellulose. Proc Natl Acad Sci 69: 1408-1412

12. Lacy PE, Kostianovsky M (1967) Method for the isolation of intact islets of Langerhans from the rat pancreas. Diabetes 16:35-39

13. Giddings SJ, Chirgwin J, Permutt MA (1981) The effects of fasting and feeding on pre-proinsulin messenger RNA in rats. $J$ Clin Invest 67: 952-960

14. McMaster GK, Carmichael GG (1977) Analysis of single- and double-stranded nucleic acids on polyacrylamide and agarose gels by using glyoxal and acridine orange. Proc Natl Acad Sci 74: 4836-4838

15. Seed B (1982) Diazotisable arylamine cellulose papers for the coupling and hybridization of nucleic acids. Nucleic Acids Res 10: $1799-1810$

16. Wahl GM, Stern M, Stark R (1979) Efficient transfer of large DNA fragments from agarose gels to diazobenzyloxymethyl-paper and rapid hybridization by using dextran sulfate. Proc Natl Acad Sci 76: 3683-3687

17. Rigby PWJ, Dieckmann M, Rhodes C, Berg P (1977) Labeling deoxyribonucleic acid to high specific activity in vitro by nick translation with DNA polymerase I. J Mol Biol 113: 237-251
18. Chick WL, Shields W, Chute RN, Lauris U (1976) A transplantable rat insulinoma. Diabetes 25: 344

19. Villa-Komaroff L, Efstratiadis A, Broome J, Lomedico P, Tizard R, Naber S, Chick W, Gilbert W (1978) A bacterial clone synthesizing proinsulin. Proc Natl Acad Sci 75: 3727-3731

20. Gazdar AF, Chick WL, Oie HK, Sims HL, King DL, Weir GC, Lauris V (1980) Continuous, clonal, insulin- and somatostatinsecreting cell lines established from a transplantable rat islet cell tumor. Proc Natl Acad Sci 77: 3519-3523

21. Rozensweig JL, Havrankova J, Lesniak MA, Brownstein $\mathbf{M}$, Roth $\mathrm{J}(1980)$ Insulin is ubiquitous in extrapancreatic tissues in rats and humans. Proc Natl Acad Sci 77: 572-576

22. Steiner DF (1976) Proteins. In: Fasman GD (ed) Handbook of biochemistry and molecular biology, Vol.3.CRC Press, Cleveland, Ohio, pp 378-381

23. Chan SJ, Episkopou V, Zeitlin S, Karathanasis SK, MacKrell A, Steiner DF, Efstratiadis A (1984) Guinea pig pre-proinsulin gene: an evolutionary compromise? Proc Natl Acad Sci 81: 5046-5050

24. Smith JE, Summers MD (1980) The bidirectional transfer of DNA and RNA to nitrocellulose or diazobenzyloxymethyl-paper. Anal Biochem 109: 123-129

25. Alwine JC, Kemp DJ, Parker BA, Reiser J, Renart J, Stark GR, Wahl GM (1979) Detection of specific RNA's or specific fragments of DNA by fractionation in gels and transfer to diazobenzyloxymethyl paper. Methods Enzymol 68: 220-242

26. Giddings S, Chirgwin J, Permutt MA (1982) Effects of glucose on insulin mRNA in rats in vivo. Diabetes 31:624

27. Guyette WA, Mutusik RJ, Rosen JM (1979) Prolactin-mediated transcriptional and post-transcriptional control of casein gene expression. Cell 17: 1013-1023

28. McKnight GS, Palmiter RD (1979) Transcriptional regulation of the ovalbumin and conalbumin genes by steroid hormones in chick oviduct. J Biol Chem 254: 9050-9058

29. McKnight GS, Lee DC, Hammarplardh D, Finch CA, Palmiter RD (1980) Transferrin gene expression: Effects of nutritional iron deficiency. J Biol Chem 255: 144-147

30. Peavy DE, Taylor JM, Jefferson LS (1978) Correlation of albumin production rates and albumin mRNA levels in livers of normal, diabetic, and insulintreated diabetic rats. Proc Natl Acad Sci 75: 5879-5883

31. Reaven EP, Gold J, Reaven GM (1979) Effect of age on glucosestimulated insulin release by the $\beta$-cell of the rat. J Clin Invest 64 : 591 599

32. Giddings SJ, Orland MJ, Weir GC, Bonner-Weir S, Permutt MA (1985) Impaired insulin biosynthetic capacity in a rat model for non-insulin dependent diabetes: studies with dexamethasone. Diabetes 34: $235-240$

33. McConaughy BL, McCarthy BJ (1967) The interaction of oligodeoxynucleotides with denatured DNA. Biochim Biophys Acta 149: $180-189$

34. Bell GI, Merryweather JP, Sanchez-Pescador R, Stempien MM, Priestley L, Scott J, Rall LB (1984) Sequence of a cDNA clone encoding human pre-proinsulin-like growth factor II. Nature 310 : $775-777$

35. Dull TJ, Gray A, Hayflick JS, Ullrich A (1984) Insulin-like growth factor II precursor gene organization in relation to insulin gene family. Nature 310: 777-781

36. Hudson P, Haley J, Cronk M, Shine J, Niall H (1981) Molecular cloning and characterization of cDNA sequences coding for rat relaxin. Nature 291: 127-131

Received: 26 October 1984

and in revised form: 26 March 1985

Dr. M. Alan Permutt

Metabolism Division

Washington University School of Medicine

660 South Euclid Avenue

St. Louis, MO 63110, USA 